\title{
Die stand van keuring van studentverpleegkundiges in 1983
}

MEV. E.S. RADEMEYER, Navorsingsassistent, Suid-Afrikaanse Verpleegstersvereniging

*MEV. H.E. STOLS, Opvoedkundige Beampte, SuidAfrikaanse Verpleegstersvereniging
PROF. J.G.P. VAN NIEKERK, Sentrale Bestuurslid, Suid-Afrikaanse Verpleegstersvereniging

"PROF. M.C. VAN HUYSSTEEN, President, Suid-Afrikaanse Verpleegstersvereniging

\section{SUMMARY}

The cbject of this study was to determine whether any form of selection is applied to student nurses and if so, which selection methods are being used in the selection of students for the basic course for registration as a general nurse or the basic integrated courses leading to registration.

All universities, colleges of nursing and hospital training schools were involved in this investigation. The investigation indicated that selection was in fact applied, but that many problems, deficiencies and needs exist. The single major need is for a specific standardised instrument for use in the selection of nurses.

\section{INLEIDING}

Keuring van personeel is altyd 'n probleem. Die keuring van studentverpleegkundiges is eweneens 'n groot kopseer vir elke verpleegadministrateur wat dit met gereelde tussenposes moet doen. Daar is geen standaardmetode of towerformule waarvolgens die beoordeling gedoen kan word nie. Vir sowel die individu as die hele beroep is daar baie op die spel wat hierdie een funksie van die verpleegadministrateur betref, en tog word dit grotendeels op 'n lukraak en subjektiewe manier uitgevoer.

In die dokumentasie van die Beroepspesifieke Bedeling vir Verpleegpersoneel in Oktober 1982 deur die Kommissie vir Administrasie, is die keuring van studentverpleegkundiges uitgewys as 'n saak wat dringende aandag moet kry. Die Adviserende Komitee oor Gesondheidsake se Subkomitee oor Verpleging het hieraan aandag geskenk. Die vraag het ontstaan oor wat in die keuring van studentverpleegkundiges in hierdie land gebeur, en daar is besluit dat die Suid-Afrikaanse Verpleegstersvereniging 'n opname sou maak om 'n beeld te kry van keuringsmeganismes wat toegepas word, om as basis te dien vir toekomstige ontwikkeling en navorsing. Die bevindinge van die opname word hier bespreek.

\section{VRAELYS EN STREEKPROEF}

'n Vraelys oor die keuring van studentverpleegkundiges vir die basiese kursus vir registrasie as algemene verpleegkundige of die basiese geïntegreerde kursusse wat tot registrasie lei, is in beide landstale opgestel. Daarin is vrae gevra oor die omvang en metode van keuring wat deur opleidingskole toegepas word.

'n Voorbeeld van die vraelys, vergesel van 'n begeleidende brief, is gestuur aan al die gesondheidsowerhede in die Republiek van SuidAfrika wat met die opleiding van studentverpleegkundiges gemoeid is en aan die universiteite wat voorregistrasie kursusse aanbied. Die betrokke departemente het die
Die navorsers wil namens die SA Verpleegstersvereniging al die respondente hartlik bedank vir hulle deelname aan hierdieprojek.

vraelys versprei na al die opleidingskole onder hulle beheer. Die opleidingskole en universiteite het die voltooide vraelys teruggestuur na die Suid-Afrikaanse Verpleegstersvereniging.

Die aantal opleidingskole volgens statistiek van die Suid-Afrikaanse Raad op Verpleging (steekproefgrootte) en die respons op die vraelys word in tabel 1 uiteengesit.

In die respons op die vraelys was daar 'n verskil tussen Blanke en Nieblanke opleidingskole ten opsigte van die keuringskriteria, dus word dit deurgaans afsonderlik in die tabelle aangedui.

Die respons was teleurstellend omdat minder as $50 \%$ van die hospitaalopleidingskole die vraelys teruggestuur het.

Daar is ook vraelyste aan kolleges vir verpleging gestuur, maar omdat hulle aangedui het dat hulle nie deel het aan die keuring van studentverpleegkundiges nie, is hierdie vraelyste by die verwerking van die gegewens weggelaat. Een kollege het aanbeveel dat albei instellings, hospitaal en kollege vir verpleging, by die keurkomitee ingesluit moet word. 
Tabel 1 Respons op vraelys oor die keuring van studentverpleegkundiges in 1983

\begin{tabular}{|l|rrr|rrr|rrr|}
\hline \multirow{2}{*}{$\begin{array}{l}\text { Opleiding } \\
\text { skool }\end{array}$} & \multicolumn{4}{|c|}{ Blank } & \multicolumn{3}{c|}{ Nieblank } & \multicolumn{3}{c|}{ Totaal } \\
\cline { 2 - 10 } & $\begin{array}{r}\text { Aantal } \\
\text { oplei- } \\
\text { ding- } \\
\text { skole }\end{array}$ & $\begin{array}{r}\text { Aantal } \\
\text { respon- } \\
\text { dente }\end{array}$ & $\begin{array}{r}\text { respon- } \\
\text { dente }\end{array}$ & $\begin{array}{r}\text { Aantal } \\
\text { oplei- } \\
\text { ding- } \\
\text { skole }\end{array}$ & $\begin{array}{r}\text { Aantal } \\
\text { respon- } \\
\text { dente }\end{array}$ & $\begin{array}{r}\% \\
\text { respon- } \\
\text { dente }\end{array}$ & $\begin{array}{r}\text { Aantal } \\
\text { oplei- } \\
\text { ding- } \\
\text { skole }\end{array}$ & $\begin{array}{r}\text { Aantal } \\
\text { respon- } \\
\text { dente }\end{array}$ & $\begin{array}{r}\% \\
\text { respon- } \\
\text { dente }\end{array}$ \\
\hline Hospitaal & 63 & 37 & 58,7 & 70 & 25 & 35,7 & 133 & 62 & 46,6 \\
Universiteit & 8 & 7 & 87,5 & 2 & 2 & 100 & 10 & 9 & 90 \\
\hline Totaal & 71 & 44 & $\mathbf{6 1 , 9}$ & $\mathbf{7 2}$ & $\mathbf{2 7}$ & $\mathbf{3 7 , 5}$ & $\mathbf{1 4 3}$ & $\mathbf{7 1}$ & $\mathbf{4 9 , 6}$ \\
\hline
\end{tabular}

\section{BEVINDINGS}

Inligting aangaande keuring van studentverpleegkundiges wat uit die opname geblyk het word hieronder uiteengesit.

\section{Die omvang van keuring}

Op die eerste vraag in die vraelys wat gelui het: Word daar enige meganisme van keuring toegepas voordat aansoekers toegelaat word tot die basiese kursus vir registrasie as algemene verpleegkundige of die basiese geïntegreerde kursusse wat lei tot registrasie? het al die respondente positief geantwoord.

\section{Algemene keuringsfaktore}

In die tweede vraag moes aangedui word of die twaalf keuringsfaktore daarin genoem as 'n riglyn of 'n onbuigsame meetinstrument gebruik word.

Die respons op dié vraag word in tabel 2 uiteengesit.

Weens verwarring wat ontstaan het oor punt 11 en 12 van tabel 2 is al hierdie gegewens onder ander meetinstrumente ingedeel. Antwoorde op hierdie item, wat dus addisionele keuringskriteria uitmaak, het die volgende ingesluit:

\section{Blanke universiteite}

- Onderhoude gestruktureer op grondslag van die Smeltzermodel en -onderhoudskedule

- Biografiese vraelys

- Punteskale vir taal, Wiskunde, Natuurwetenskap en simbole vir die twee beste vakke

_ 'n Formule vir akademiese prestasie

Blanke hospitaalopleidingskole

- Vraelys oor vakansiewerk in hospitaal

- Vakansiewerk vir alle aansoekers

\section{TABEL 2 Die gebruik van keuringsfaktore as riglyn of onbuigsame meetinstrumente}

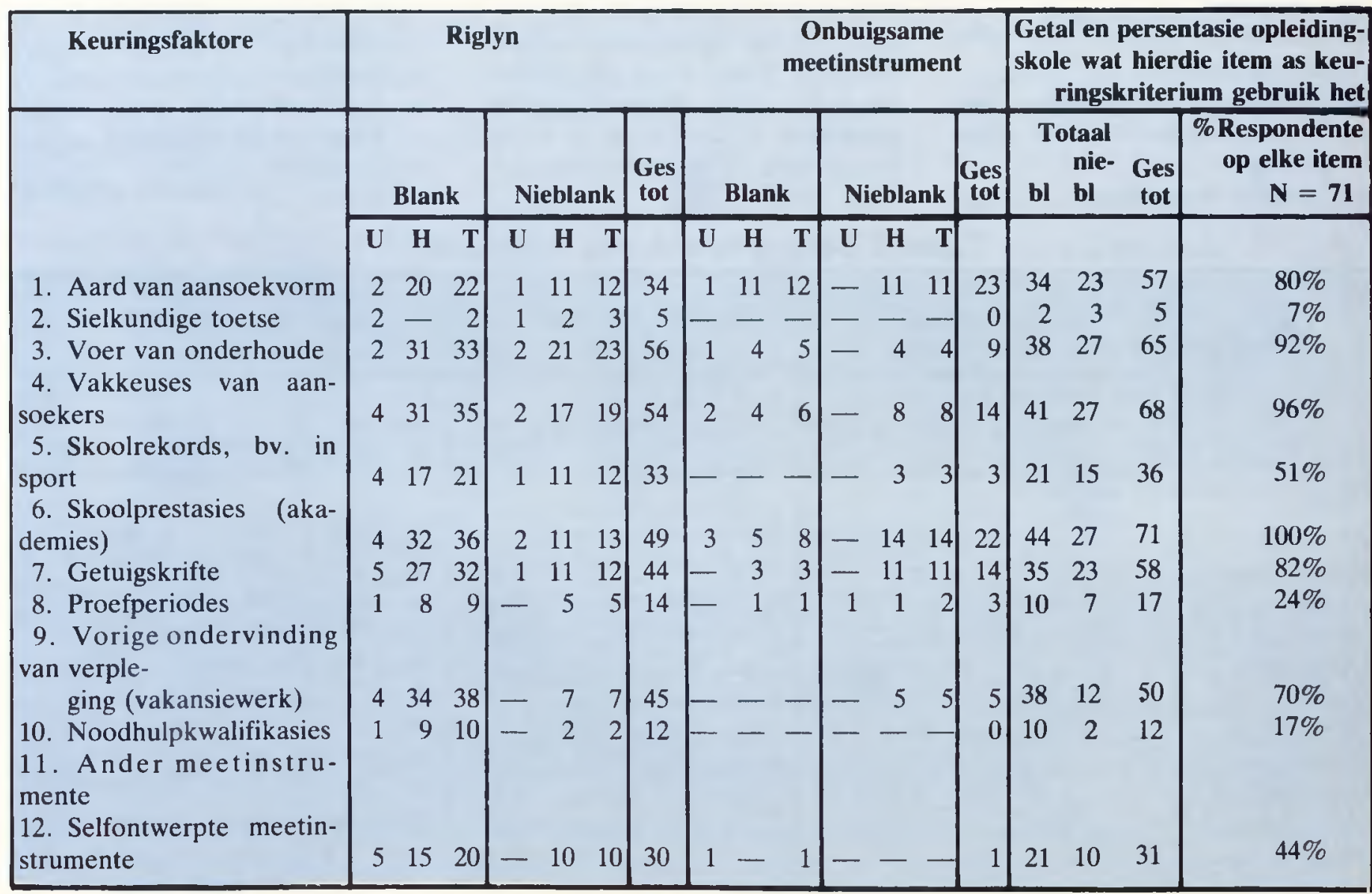

SLEUTEL TOT AFKORTINGS:

$$
\begin{aligned}
& \mathrm{U}=\text { Universiteit } \\
& \mathrm{H}=\text { Hospitaalopleidingskool } \\
& \mathrm{T}=\text { Totaal }
\end{aligned}
$$

$\mathrm{B} 1$ = Blank

Niebl $=$ Nieblank

GES TOT $=$ Gesamentlike totaal, Blank en Nieblank 
- Onderhoudskedules

- Nominasievorm vir lede

- Vertroulike verslae van skoolhoof

- Vraelys oor agtergrondskennis wat aansoeker omtrent verpleging besit, asook persoonlike sienings van student oor die beroep en studie

- Matriekeksamenuitslae vir aanbeveling na graad of diplomakursusse

- Mediese sertifikaat

- Gesondheidsvraelys

- Prognoseverslae

- Persoonsnommer

- Hospitaalpersoneelkode se riglyne

\section{Nieblanke universiteit}

- Onderhoude gestruktureer op grondslag van die Smeltzermodel

- Sweedse Graderingskaal (Swedish Rating Scale) vir skoolprestasie

\section{Nieblanke hospitaalopleidingskole}

- Kerkverband (vir identifisering van Jehovagetuies)

- Verslae van kliniese situasies

- Vraelyste

- Maksimum periode van drie jaar na matriek

- Vordering in eerste blok

- Mediese ondersoek voor aanstelling

- Plaaslike aansoekers
- Aanlegtoetse

- Geboortesertifikaat

- Skoolsertifikaat St. 8 en 10

- Kwitansie vir LEBNA

- Behoeftige aansoeker

- Observasie gedurende vakansiewerk in hospitaal

\section{Opmerkings oor algemene keuringsfaktore}

Tabel 2 toon duidelik die belang wat aan skoolprestasie as keuringsfaktor geheg word, alhoewel dit in die meerderheid gevalle uitgewys is as 'n riglyn en nie 'n onbuigsame meetinstrument nie. Die vakkeuses, wat noú hiermee saamhang, word ook byna deurgaans in aanmerking geneem, terwyl onderhoudvoering amper as net so belangrik geag word. Dit is opmerklik dat getuigskrifte nog in so 'n groot mate gebruik word, terwyl dit as eienaardig voorkom dat die aansoekvorm net in $80 \%$ van gevalle vir keuring gebruik word. Die $7 \%$ opleidingskole van enige aard wat nog sielkundige toetsing as keuringsfaktor gebruik, is nou die uitsondering

\section{Vakkeuses}

Daar is reeds aangetoon dat vakkeuses ' $n$ baie belangrike keuringsfaktor is. Vraag 3 van die vraelys het gevra of die skoolvakke, soos uiteengesit in tabel 3, as 'n toelatingsvereiste of 'n aanbeveling gebruik word.
Die respons op dié vraag word in tabel 3 uiteengesit. Onder die laaste item, naamlik Ander het respondente die volgende aangedui:

\section{Blanke universiteite}

- Meer natuurwetenskaplike vakke as die gewone aantal word verkies

- Akademiese meetinstrumente vir vakke

\section{Blanke hospitaalopleidingskole}

- Kombinasie van natuurwetenskaplike vakke

- Ten minste twee akademiese vakke vereis

- Aan mense wat nie oor Biologie beskik nie, word die geleentheid gegun om dit te volg

- Huishoudkunde

- Ekonomie

- Handelsreg

- Handelswiskunde

- Matriekulasievrystelling

- Akademiese vakke kry voorkeur bo praktiese vakke

\section{Nieblanke universiteite}

Geen

Nieblanke hospitaalopleidingskole

- Ten minste twee natuurwetenskaplike vakke

- 'n Derde taal bekend aan alle etniese groepe 'n vereiste

- Landbou

- Huishoudkunde

- Enige rekenkundige vak

- Biochemie

- Fisika

Tabel 3 Belangrikheid van vakkeuses

\begin{tabular}{|c|c|c|c|c|c|c|c|c|c|c|c|c|c|c|c|c|c|c|}
\hline \multirow[t]{3}{*}{ Vak } & \multicolumn{7}{|c|}{$\begin{array}{l}\text { Hierdie vakke is 'n } \\
\text { toelatingsvereiste }\end{array}$} & \multicolumn{7}{|c|}{$\begin{array}{r}\text { Hierdie vakke dien } \\
\text { as aanbeveling }\end{array}$} & \multicolumn{4}{|c|}{$\begin{array}{l}\text { Getal en persentasie opleiding- } \\
\text { skole wat hierdie item as keu- } \\
\text { ringskriterium gebruik het }\end{array}$} \\
\hline & \multicolumn{3}{|c|}{ Blank } & \multicolumn{3}{|c|}{ Nieblank } & \multirow[t]{2}{*}{$\begin{array}{c}\text { Ges } \\
\text { tot }\end{array}$} & \multicolumn{3}{|c|}{ Blank } & \multicolumn{3}{|c|}{ Nieblank } & \multirow[t]{2}{*}{$\begin{array}{c}\text { Ges } \\
\text { tot }\end{array}$} & \multicolumn{2}{|c|}{$\begin{array}{c}\text { Totaal } \\
\text { Bl nie bl }\end{array}$} & \multirow[t]{2}{*}{ Ges tot } & \multirow[t]{2}{*}{$\begin{array}{c}\text { \% respondente } \\
\text { op elke item } \\
N=68\end{array}$} \\
\hline & & $\mathbf{H}$ & & & H & & & $\mathbf{U}$ & $\mathbf{H}$ & & & $\mathbf{H}$ & & & & & & \\
\hline Wiskunde & 2 & 2 & 4 & 1 & 7 & 8 & 12 & 4 & 31 & 35 & 1 & 17 & 18 & 53 & 39 & 26 & 65 & $96 \%$ \\
\hline Wetenskap & 2 & 4 & 6 & - & 8 & 8 & 14 & 4 & 33 & 37 & 2 & 15 & 17 & 54 & 43 & 25 & 68 & $100 \%$ \\
\hline Biologie & 1 & 6 & 7 & 一 & 16 & 16 & 23 & 5 & 29 & 24 & 2 & 9 & 11 & 45 & 41 & 27 & 68 & $100 \%$ \\
\hline Fisiologie & 1 & 5 & 6 & - & 13 & 13 & 19 & 3 & 28 & 31 & 1 & 11 & 12 & 43 & 37 & 25 & 62 & $91 \%$ \\
\hline Afrikaans & 3 & 22 & 25 & 1 & 9 & 10 & 35 & 2 & 9 & 11 & - & 7 & 7 & 18 & 36 & 17 & 53 & $78 \%$ \\
\hline Engels & 3 & 23 & 26 & 1 & 22 & 23 & 49 & 2 & 9 & 11 & 一 & - & - & 11 & 37 & 23 & 60 & $88 \%$ \\
\hline 'n Derde taal & - & - & 一 & - & 10 & 10 & 10 & 3 & 10 & 13 & 1 & 6 & 7 & 20 & 13 & 17 & 30 & $44 \%$ \\
\hline Geskiedenis & - & - & 一 & 一 & 2 & 2 & 2 & 2 & 19 & 21 & 1 & 6 & 7 & 28 & 21 & 9 & 30 & $44 \%$ \\
\hline Aardrykskunde & - & 一 & 一 & 一 & 1 & 1 & 1 & 2 & 17 & 19 & 1 & 6 & 7 & 26 & 19 & 8 & 27 & $40 \%$ \\
\hline Rekenkunde & - & 1 & 1 & 一 & 4 & 4 & 5 & 2 & 14 & 16 & 1 & 9 & 10 & 26 & 16 & 14 & 30 & $44 \%$ \\
\hline Ander & 一 & - & 一 & 一 & 1 & 1 & 1 & 2 & 10 & 12 & 一 & 5 & 5 & 17 & 12 & 6 & 18 & $26 \%$ \\
\hline
\end{tabular}

SLEUTEL TOT AFKORTINGS:

$\mathrm{U}=$ Universiteit

$\mathbf{H}=$ Hospitaalopleidingskool

$\mathrm{T}=$ Totaal
$\mathrm{Bl}=\mathrm{Blank}$

Niebl $=$ Nieblank

GES TOT $=$ Gesamentlike totaal, Blank en Nieblank 
Superintendent van die hospitaal

Hoofmatrone, verpleegdiensbestuurder-in-bevel

Ander verpleegdiensbestuurders

Verpleegkundige in beheer van 'n saal

Prinsipaal van kollege

Hoof van die Departement Verpleegkunde (Universiteit)

Dosent

Ander

\begin{tabular}{|rrr|rrr|r|r|}
\hline & Blank & & \multicolumn{3}{|c|}{ Nieblank } & \multicolumn{2}{|c|}{$\begin{array}{c}\text { Getal en persentasie } \\
\text { opleiding skole wat } \\
\text { hierdie item aangedui het }\end{array}$} \\
\hline U & H & T & U & H & T & Ges tot & \% \\
& & & & & & N $=65$ \\
\hline 4 & 2 & 6 & 1 & - & 1 & 7 & $11 \%$ \\
4 & 30 & 34 & 1 & 21 & 22 & 56 & $86 \%$ \\
1 & 22 & 23 & - & 18 & 18 & 41 & $63 \%$ \\
- & 1 & 1 & - & 6 & 6 & 7 & $11 \%$ \\
- & - & - & - & 7 & 7 & 7 & $11 \%$ \\
4 & 3 & 7 & 1 & 1 & 2 & 9 & $14 \%$ \\
1 & 3 & 4 & - & 8 & 8 & 12 & $18 \%$ \\
3 & 11 & 14 & - & 4 & 4 & 18 & $28 \%$ \\
\hline
\end{tabular}

SLEUTEL TOT AFKORTINGS: $\mathrm{U}=$ Universiteit $\quad \mathrm{T}=$ Totaal

$\mathrm{H}=$ Hospitaalopleidingskool $\quad$ Ges tot $=$ Gesamentlike totaal - Blank en Nie-blank

\section{Enkele opmerkings oor vakkeuses}

Tabel 3 wys baie duidelik die hoë waarde wat aan die natuurwetenskappe geheg word. Die vier natuurwetenskaplike vakke, naamlik Wiskunde, Wetenskap, Biologie en Fisiologie word almal deur meer as $90 \%$ respondente vir keuring gebruik. Dit is verder opmerklik dat dié vakke in die oorgrote meerderheid van gevalle as aanbeveling en nie as toelatingsvereiste dien nie. Daar kan verder op gelet word dat 24 uit 27 respondente in die Nieblanke groep, dus $98 \%$, Engels as toelatingsvereiste stel.

\section{Onderhoudvoering}

Vraag 4 van die vraelys het gegaan oor onderhoudvoering. In item 3 van tabel 2 het $65(92 \%)$ van die respondente aangedui dat hulle onderhoude met die kandidate voer.

\section{Persone betrokke by onderhoudvoering}

Die eerste deel van vraag 4 het gevra wie die onderhoude met kandidate voer. Tabel 4 wys die besonderhede.

Onder item Ander by tabel 4 het respondente die volgende aangedui:

\section{Blanke universiteite}

- Verteenwoordiger van Departement Hospitaaldienste

- Direkteur van verpleging

- Verteenwoordigers van universiteit en hospitaal

\section{Blanke opleidingshospitale}

- Matrone gemoeid met aanstellings

- Studentevoorligter

- Mediese superintendent in geval van applikant met bevraagtekende mediese geskiedenis

- Indien nodig die prinsipaal van kollege of hoof van departement verpleegkunde

- Verpleegdiensbestuurder gemoeid met personeel

- Spesiale komitee in geval van grensgevalle

- Kliniese verpleegpersoneel

Nieblanke universiteite

Geen

\section{Nieblanke opleidinghospitale}

- Organiseerder van verpleegdienste

- Kliniese departement

- Kliniese instruktrise

Enkele opmerkings oor persone betrokke by onderhoude

Dit blyk duidelik uit tabel 4 dat die hoof- en ander verpleegdiensbestuurders die belangrikste aandeel in die onderhoudvoering met kandidate het. Dit is opmerklik dat die formele onderwyspersoneel naamlik die prinsipaal van die kollege en dosente, tans onderskeidelik net in $11 \%$ en $18 \%$ van die gevalle aan die onderhoudvoering deelneem.
Faktore betrokke by onderhoudvoering

Die tweede deel van vraag 4 het gehandel oor die faktore wat in aanmerking geneem word tydens onderhoudvoering. 'n Aantal faktore (volgens die a angepaste Smeltzer-model) is gelys en respondente moes aandui watter hulle in aanmerking neem by onderhoudvoering. Tabel 5 toon die uitslag.

Onder item Ander by tabel 5 het respondente die volgende aangedui:

\section{Blanke universiteite}

- Onderhoudskedule

- Aangepaste Smeltzer-model

Blanke hospitaalopleidingskole

- Entoesiasme

- Mediese vraelys

- Taalbevoegdheid

- Persoonlike houding

- Stiptelikheid

- Oogkontak

- Klasposisie in skool

- Leiersposisie in skool

- Voorkeurvakke

- Leervakke

- Huislike agtergrond

- Leerprobleme

- Emosionele toestand

- Of applikant 'n Suid-Afrikaner of buitelander is

- Gesondheids- of emosionele probleme

- Die siening van eggenoot in geval van 'n getroude persoon 
Tabel 5 Faktore in ag geneem tydens persoonlike onderhoudsvoering

Fisiese voorkoms

Netheid en kleding

Stemtoon

Taalgebruik en spraak

*Vaardigheid

Gesindheid

Emosionele volwassenheid

Aanpasbaarheid

Belangstelling in verpleging

Begrip van kursus

Begrip van verpleging

Toewyding

Vermoë om intelligent te kommunikeer Ander

\begin{tabular}{|c|c|c|c|c|c|c|c|}
\hline \multicolumn{3}{|c|}{ Blank } & \multicolumn{3}{|c|}{ Nieblank } & \multicolumn{2}{|c|}{$\begin{array}{l}\text { Getal en persentasie van } \\
\text { opleidingskole wat hierdie } \\
\text { item as keurings- } \\
\text { kriterium gebruik }\end{array}$} \\
\hline $\mathbf{U}$ & $\mathbf{H}$ & $\mathbf{T}$ & $\mathbf{U}$ & $\mathbf{H}$ & $\mathbf{T}$ & Ges Tot & $\mathbf{N}=65$ \\
\hline 3 & 36 & 39 & 2 & 24 & 26 & 65 & $100 \%$ \\
\hline 3 & 36 & 39 & 2 & 21 & 23 & 62 & $95 \%$ \\
\hline 3 & 23 & 26 & 1 & 14 & 15 & 41 & $63 \%$ \\
\hline 3 & 33 & 36 & 2 & 14 & 16 & 42 & $65 \%$ \\
\hline 2 & 24 & 26 & 1 & - & 1 & 27 & $42 \%$ \\
\hline 3 & 33 & 36 & 2 & 22 & 24 & 60 & $92 \%$ \\
\hline 3 & 30 & 33 & 1 & 18 & 19 & 52 & $80 \%$ \\
\hline 3 & 25 & 28 & 1 & 11 & 12 & 40 & $62 \%$ \\
\hline 3 & 34 & 37 & 2 & 25 & 27 & 64 & $98 \%$ \\
\hline 3 & 28 & 31 & 1 & 16 & 17 & 48 & $74 \%$ \\
\hline 3 & 34 & 37 & 1 & 17 & 18 & 55 & $85 \%$ \\
\hline 3 & 23 & 26 & 1 & 16 & 17 & 43 & $66 \%$ \\
\hline 3 & 34 & 37 & 2 & 20 & 22 & 59 & $91 \%$ \\
\hline 2 & 10 & 12 & - & 7 & 7 & 19 & $29 \%$ \\
\hline
\end{tabular}

"Hierdie item is per abuis in die Engelse vraelys uitgelaat, gevolglik word dit nie aangedui deur respondente wat die Engelse vraelys verkies het nie.

\section{SLEUTEL TOT AFKORTINGS:}

$$
\begin{aligned}
& \mathbf{U}=\text { Universiteite } \\
& \mathbf{H}=\text { Hospitaalopleidingskool } \\
& \mathrm{T}=\text { Totaal }
\end{aligned}
$$

$\mathrm{Bl}=$ Blank

Niebl = Nieblank

Ges tot $=$ Gesamentlike totaal, Blank en Nieblank
- Huislike verpligtings

- Stokperdjies

- Belangstellings

- Of applikant getroud is

- Kerkverband

- Motivering ten opsigte van beroep

- Verwisseling van skole

- Of applikant 'n dagskolier of kosganger is

\section{Nieblanke universiteite}

Aangepaste Smeltzer-model se onderhoudskedule

\section{Nieblanke hospitaalopleidingskole}

- Algemene kennis

- Stokperdjies

- Handskrif

- Algemene observasie

- Sosiale agtergrond

- Taalbevoegdheid

- Gesondheidstoestand

- Ongetroude moederskap

- Kerkverband

- Kommunikasie met etniese groepe in area

- Massa en Lengte

- Ooglopende gebreke

- Bevolkingsgroep

- Ouderdom 18 - 25 behalwe in uitsonderlike gevalle
Enkele opmerkings oor faktore by onderhoudvoering

Uit die reaksie op hierdie vraag vermoed die navorsers dat dit moontlik 'n leidende vraag was, daarom word daar nie nou verdere aandag daaraan gegee nie.

\section{Proefperiodes}

Vraag 5 het oor proefperiodes gehandel. In item 8 van tabel 2 het 17 respondente $(24 \%)$ aangedui dat hulle proefperiodes as keuringsfaktor gebruik.

\section{Kriteria vir beoordeling}

Op die vraag volgens watter kriteria kandidate na die proefperiode gemeet word, was die antwoorde soos volg:

\section{Blanke universiteite \\ - Eksamenuitslae}

\section{Blanke hospitaalopleidingskole}

- Blokuitslae

- Belangstelling

- Entoesiasme

- Aanpassingsvermoë

- Menslike verhoudings
- Vordering

- Oplettendheid

- Moontlike sielkundige probleme

- Saalevaluasie

- $100 \%$ bywoning van saaldemonstrasies

- Aflê van minimum vereiste vaardigheidstoetse

Nieblanke universiteite

- Onderhoud gebaseer op Smeltzer-skaal na 'n tweeweekproefperiode

- Eksamenuitslae

Nieblanke hospitaalopleidingskole

- SA Raad op Verpleging se regulasies

- Teoretiese en praktiese prestasie

- Gedrag

- Swangerskap

- Blokuitslae

- Kliniese evaluasie

- Aanbeveling van prinsipaal van kollege na eerste kursus

- Aanpassingsvermoë

- Insig

- Produktiwiteit

- Menslike verhoudings

- Verantwoordelikheidsin

- Betroubaarheid 


\section{Oriënteringsperiode}

Op die vraag of 'n oriënteringsperiode toegepas word indien 'n proefperiode nie gebruik word nie, het 5 Blanke universiteite, 33 Blanke hospitaalopleidingskole, geen Nieblanke universiteite en $18 \mathrm{Nie}-$ blanke hospitaalopleidingskole positief geantwoord - dus 56 uit 71 respondente $(80 \%)$.

\section{Probleme, leemtes en behoeftes}

Die laaste item in die vraelys het gevra dat probleme, leemtes en behoeftes deur respondente aangedui moet word. Die volgende lys van probleme, leemtes en behoeftes is uit die respons saamgestel. Soortgelyke punte is bymekaargevoeg en in volgorde van hoogste tot laagste aantal respondente wat dit genoem het, gegee. Die aantal respondente wat elke punt gestel het, word in hakies agter die stelling aangedui.

\section{Alle Blanke opleidingsinstansies (universiteite en hospitaalopleiding- skole)}

- Beperkte aantal aansoekers bemoeilik keuring. Keuring kan derhalwe nie streng toegepas word nie en aansoekers wat aan minimumvereistes beantwoord word in diens geneem (21)

- Beroepsvoorligting by skole is onvoldoende en het talle leemtes (9)

- As gevolg van afstand geskied keuring slegs op papier (7)

- Ten spyte van swak skooluitslae en foutiewe vakke ontwikkel kandidate tot suksesvolle verpleegstudente (5)

- Daar is 'n gebrek aan objektiwiteit in getuigskrifte (5)

- Daar is 'n groot behoefte aan 'n eenvormige, moontlik gestandaardiseerde keuringsmetode wat spesiaal vir verpleegkundiges ontwerp is (4)

- Studente is swak ingelig oor akademiese en emosionele eise wat die beroep verg (2)

- Keuringskriteria kan nie werklik vasgestel word nie omdat daar te veel veranderlikes is (2)

- Dikwels is verpleging as loopbaan 'n heenkome omdat die student by ander instansies afgekeur is (1)
Alle Nieblanke opleidingsinstansies (universiteite en hospitaalopleidingskole)

- Beroepsvoorligting by skole is onvoldoende en foutief (8)

- Persoonlike onderhoude word deur afstande bemoeilik (6)

- Studente met swak simbole doen aansoek vir verpleging - sterk kandidate gaan na universiteite (6)

- Getuigskrifte is onbetroubaar (3)

- Die motivering van baie aansoekers is suiwer finansiëel en met die oog op status (3)

- Moeilik om kandidate met geskikte akademiese kwalifikasies te kry (2)

- Swak akademiese opleiding (2)

- Standaard van skoolopvoeding verskil van area tot area (1)

- Aansoekers het 'n gebrek aan algemene kennis (1)

- Daar bestaan 'n leemte wat betref koördinasie tussen verpleegopvoeding en algemene opvoeding (1)

- Probleme word ondervind met getroude aansoekers veral met betrekking tot inwoning (1)

- Hoe ouer die aansoeker hoe moeiliker die aanpassing (1)

- Baragwanath het te min poste vir die aantal aansoekers (1)

- Etniese probleme ontstaan (1)

- Kultuurskok beïnvloed aanpassing (1)

- Nuwe Soweto-geslag is 'n subkultuur met variasie in waardes (1)

- Hoogste uitval is as gevolg van swangerskap (1)

- Insig by Swart studente ontbreek (1)

- Meetinstrumente is nie in staat om fyner persoonlikheidstrekke te meet nie (1)

\section{Aanbevelings}

Op 'n versoek om voorstelle te maak oor hoe die bogenoemde probleme, leemtes en behoeftes opgelos kan word is die volgende aanbevelings deur respondente gemaak:

\section{Alle Blanke opleidingsinstansies (universiteite en hospitaalopleiding- skole)}

- Aanlegtoetse spesiaal vir verpleegkundiges behoort ontwerp te word - dit hoef nie IK-toetse in te sluit nie (6)

- Keuring moet eerder op grond van simbole as vakkeuses geskied (3)

- Skoolhoof se verslag oor student moet meer gewig dra (3)

- Enige redelike kandidaat moet die geleentheid kry om kursus te probeer (2)

- Langer periodes voor registrasie by SARV wat dan as 'n proefperiode kan dien (2)

- Klem moet op goeie menslike verhoudings val (2)

- Finale keuring na ses maande (1)

- Volledige inligtingstukke insake die verpleegberoep behoort aan elke voornemende verpleegkundige beskikbaar gestel te word (1)

- Mense wat keuring toepas moet opgelei wees daarvoor, soos sielkundiges, sosioloë of opvoedkundiges (1)

- Biologie moet baie sterk by skoliere aanbeveel word (1)

- Daar moet op goeie gebruik van albei landstale gelet word angesien dit sukses in die leerproses kan bepaal (1)

- Studente met 'n handelsmatriek moet bevraagteken word (1)

- Die Senior Sertifikaat as vereiste is te laag - kandidaat moet oor ten minste twee hoërgraadvakke beskik (1)

- Groepering van studente vir verskillende kursusse voor registrasie by SARV (1)

- Daar moet ook onderhoude met ouers gevoer word (1)

- Klasonderwyser kan by keuring betrek word (1)

- Kollegeverslae kan as definitiewe riglyn vir voortgaan met kursus dien (1)

- Student moet meer ondersteuning, toesig en oriëntasie ontvang (1)

- Werwingsbeamptes in verskillende streke (1)

- Skoliere behoort identiteitsdokumente op 16 jaar gereed te hê (1) 
Alle Nieblanke opleidingsinstansies (universiteite en hospitaalopleidingskole)

- Sielkundige toetse en beoordelingskale spesiaal ontwerp vir voornemende verpleegkundestudente (11)

- Vakansiewerk vir voornemende studente om besluit te verstewig (3)

- Studente moet so gou moontlik na matriek met kursus begin, anders gaan gebruik van Engels verlore (1)

- Verpleegkundige beroepsvoorligtingsprogramme behoort oor TV aangebied te word (1)
- Reklamebeamptes vir verpleging in elke hospitaal of streek (1)

- Beroepsvoorligting behoort reeds in die laerskool aangebied te word sodat vakke reg gekies kan word (1)

- Goeie simbole in Engels en natuurwetenskaplike vakke is belangrik vir sukses (1)

- Keuringskomitee moet matrone en dosente in beheer insluit (1)

\section{SLOTOPMERKINGS}

Wat baie duidelik uit hierdie opname na vore kom, is dat almal keuring doen, maar op wyd uiteenlopende maniere. Die klem is of faktore wat uit ondervinding geblyk het tot 'n redelike mate van sukses kan lei, of op subjektiewe voorkeure berus.

Dit is duidelik dat daar oneindig probleme is, soos blyk uit die lang lys probleme, leemtes en behoeftes wat genoem is. Die een enkele behoefte wat die opname aantoon is egter dat verpleegkundiges 'n eiesoortige, gestandaardiseerde keuringsinstrument wil hê om te gebruik. Daar moet nou daadwerklik aan die daarstelling van so ' $n$ instrument gewerk word.

\section{Voltooide navorsing Completed Research}

\section{AN INVESTIGATION INTO THE PROBLEM OF TEACHING PRIMARY HEALTH CARE TO STUDENT NURSES}

\author{
John Gordon Jeffries \\ Magister Curationis, Nursing Education, \\ University of Port Elizabeth
}

Many authorities in the health field such as WHO, doctors and nurse practitioners in the field of community health, health administrative authorities in the world as a whole and in Southern Africa (including the Republic of South Africa), believe that the nurse practitioner has an increasingly important role to play in the provision of primary health care. However, this objective can only be fulfilled if the professional education he receives in primary health care is adequate. This can create a problem and leads to the question: Is this education in primary health care the student nurse receives at basic and postbasic level adequate to prepare him for the role of a primary health care nurse?

In an attempt to answer this question the researcher undertook this study. The hypothesis which this study will attempt to prove is that the teaching of primary health care to student nurses undertaking a basic degree or diploma in nursing science is inadequate

A preliminary examination of several definitions of primary health care was undertaken in order to develop a working definition of this concept. This definition of primary health care is based on the definitions of WHO, several medical and nursing authorities in the field of primary health care, the South African Nursing Council and the Department of Health. It is the task of the latter authority to implement primary health care in the Republic of South Africa.

Primary health care is viewed as first contact health care offered to a client or patient by a lay-worker, a nurse or a doctor. This care is offered in the patient's home, in an improvised clinic set up by a nurse. in a community health care centre, a local authority poly-clinic, in a provincial day hospital or an out-patient's department, or a hospital or a doctor's consulting rooms. This care may be promotive, preven- tive, curative, rehabilitative or maintenance treatment primary health care.

The Nursing Act and other health legislation makes provision for the ducation and preparation of the nurse practitioner in primary health care and tor him to exercise his independent and dependent (evolving or extended) role as a nurse practitioner. This also enables the nurse-teaching faculty to develop a curriculum that will, at theoretical and clinical level, enable the student nurse to be prepared for a primary health care role and for the educational objectives in this regard to be realised.

In this study the history of the development of modern professional nursing and education in Britain, the United States of America and Southern Africa is briefly discussed. In all three countries the collegiate system of educating nurses was first developed. Later hasic and higher degree courses in nursing science were instituted. In the Republic the former South African Trained Nurses' Association and the present South African Nursing Association played an important role in the development of nursing education.

A short literature study was also made on curricular conceptual frameworks in general education and in nursing education. Chater's curricular conceptual framework was used to develop criteria against which to test the adequacy of the curriculum developed for teaching primary health care to student nurses who undertake a basic degree or diploma in nursing course.

To obtain the data for this study two questionnaires were composed by the researcher and sent to 60 institutions where student nurses who undertake a basic degree or diploma in nursing science receive their theoretical education and to 60 institutions where these student nurses receive clinical teaching and practice in primary health care. These were to be completed by the nursing personnel. The sample of institutions to which questionnaires were sent was randomly selected.

The researcher believes that the hypothesis that student nurses are not being adequately prepared for their primary health care role has been substantiated in this sample. However, although certain tendencies are demonstrated, the sample is too small to generalize its results to a larger population of primary health care institutions. A larger sample might be more fruitful. The main value of this study lies in the development of a research technique 